\title{
Forest Fragments' Contribution to the Natural Biological Control of Spodoptera frugiperda Smith (Lepidoptera: Noctuidae) in Maize
}

\author{
Eduardo Henrique Santana Sousa, Michela Costa Batista Matos, Ruanno Silva Almeida \\ and Adenir Vieira Teodoro ${ }^{* 1,2}$ \\ ${ }^{1}$ Universidade Estadual do Maranhão; Campus Universitário Paulo VI, s/n; 65054-970; São Luís - MA - Brasil. \\ ${ }^{2}$ Embrapa Tabuleiros Costeiros; Av. Beira Mar, 3250, 49025-040; Aracaju - SE - Brasil
}

\begin{abstract}
The present work evaluated the influence of forest distance on predatory solitary wasps' abundance and richness and its relation to the natural biological control of the fall armyworm (Spodoptera frugiperda Smith - Lepidoptera: Noctuidae) in maize. The study consisted of two parallel lines of six experimental maize plots located at an increasing distance from a forest edge. Four trap-nests were placed in the vertices of each plot of the first line to evaluate the abundance and species richness of predatory solitary wasps. The larvae of the fall armyworm were sampled weekly by inspecting ten randomly chosen plants per plot. Predatory solitary wasp abundance (but not species richness) decreased whilst the fall armyworm abundance increased with the distance from the forest. Moreover, population densities of predatory solitary wasps and the fall armyworm were negatively correlated. Results suggested that the crop plantations located near forest fragments might benefit from the reduced pest problems as a result of increased natural biological control.
\end{abstract}

Key words: predatory solitary wasps, fall armyworm, ecosystem services, natural biological control

\section{INTRODUCTION}

Managed ecosystems make up a large portion of tropical landscapes compared to natural ecosystems such as forests (Western and Pearl, 1989), which are frequently patchily distributed in an agricultural matrix (Schelhas and Greenberg, 1996; Laurance and Bierregaard, 1997). Populations inhabiting the fragmented habitats, especially species living in agroecosystems distant from the natural or near-natural habitats, become isolated from the source populations in large natural habitats (Klein et al., 2006), potentially causing loss of biodiversity. Anthropogenically induced degradation and simplification of natural habitat structures are major causes of the current loss of biodiversity worldwide (Davies et al., 2000), which has impacted negatively on ecosystem services such as natural biological control (MEA, 2005).

Predatory wasps (Hymenoptera: Sphecidae, Vespidae) are considered important indicators of environmental quality (Klein et al., 2002a) and contribute to agroecosystem functioning because their larvae feed on some pest species (Harris, 1994; Losey and Vaughan, 2006). However,

*Author for correspondence: adenir.teodoro@pq.cnpq.br 
anthropogenic habitat fragmentation may lead to the extinction of predatory wasps, affecting the natural biological control in important cash crops (Didham et al., 1996; Klein et al., 2002a,b).

Forest patches near the crop plantations have been shown to increase the local abundance and diversity of predatory solitary wasps (Holzschuh et al., 2009). Forests and other near-natural habitats such as set aside areas may provide resources for natural enemies, including predatory wasps (Tscharntke et al., 2007). Thus, crop fields located in the vicinity of natural or near-natural habitat remnants can benefit from the increased enemy abundance (Tscharntke et al., 1998) and diversity (Clough et al., 2005; Klein et al., 2002a).

Trap nests enabled to study communities of solitary above-ground nesting wasps under standardized conditions (Tscharntke et al., 1998). Trap nests have been utilized in several studies in tropical forest and agricultural ecosystems as predatory solitary wasps use holes of suitable diameter for nesting (Klein et al., 2002a; Tylianakis et al., 2005; Holzschuh et al., 2009; Sobek et al., 2009).

Maize (Zea mays L.) is one of the most important cash crops in tropical America and is a key staple food for smallholders in the northeastern state of Maranhão, Brazil. The fall armyworm (Spodoptera frugiperda Smith - Lepidoptera: Noctuidae) is the main pest affecting maize, especially from seedling emergence until flowering (Cesconetto et. al., 2005). The larvae of the fall armyworm are naturally attacked by the predatory wasps (Wyckhuys and O'Neil, 2006), whose populations may be affected by the distance from natural forest fragments.

The aim of this work was to evaluate the influence of forest distance on the predatory solitary wasps' abundance and richness and its related impact on the biological control of the fall armyworm in maize.

\section{MATERIALS AND METHODS}

\section{Study area}

The study was carried out during a cycle of maize cultivation in 2009 at the campus of the Maranhão State University (UEMA), São Luís, Maranhão State, Brazil $\left(2^{\circ} 35^{\prime} \mathrm{S}, 44^{\circ} 12^{\prime} \mathrm{W}\right)$. The climate of the region, according to Köppen classification, is AW' type with well defined rainy and dry seasons from January to June and from July to December, respectively (LABGEO, 2002). Mean annual precipitation is around $2.100 \mathrm{~mm} /$ year. The predominant soil type in the experimental site is argilluvic soil (EMBRAPA, 2006).

\section{Trap Nests}

Each trap nest consisted of 12 castor bean plant (Ricinus communis L.) internodes with inner diameters ranging from $2-20 \mathrm{~mm}$ to $20 \mathrm{~cm}$ in length, wrapped round with wire (Fig. 1). Trap nests were hung on a wooden post at $1.5 \mathrm{~m}$ above the ground with a $20 \mathrm{~cm}$ wire. Sticky glue (Isca Cola, Ijuí, Brazil) was applied around each wire base to deter the ants and other arthropods.

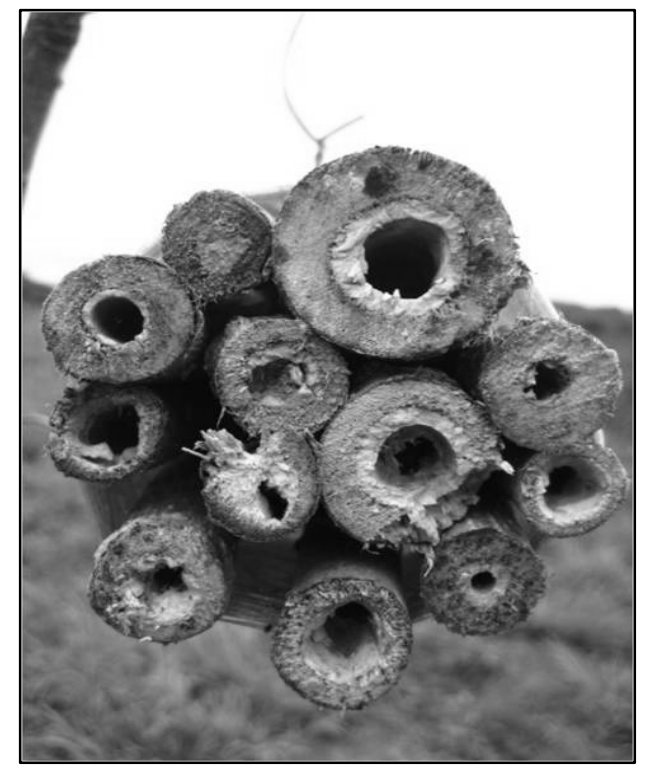

Figure 1 - A trap nest for predatory solitary wasps. 


\section{Study Design and experimental plots}

The secondary forest fragment (hereafter forest) of about 3ha was dominated by palm trees, mainly babassu (Attalea speciosa Mart.) and tucum (Astrocarium vulgare Mart.). The species richness and abundance of predatory wasps as well as the abundance of the fall armyworm were evaluated in 12 experimental plots $(6 \times 6 \mathrm{~m})$ of maize variety BRS-Caatingueiro sown in two parallel lines (80 $\mathrm{m}$ between lines). Each plot in the two lines was sited at an increasing distance from the forest edge $(0,40,80,120,160,200 \mathrm{~m})$. Four trap nests were placed in the corners of each plot in the first line while the plots in the second line remained without trap nests to evaluate if the presence of trap nests would improve the natural biological control. Once a week the trap nests were inspected and all the occupied internodes were removed and replaced with empty ones of the same diameter. The internodes were then taken to the laboratory and placed in standardized cardboard boxes until adult emergence to assess the predatory solitary wasps' richness and abundance. After the adults had emerged, species were separated in morphotypes and sent for identification to the species level. Voucher specimens of the wasps were deposited in the collection of the Department of Zoology, Federal University of Paraná (DZUP), Curitiba, Brazil.

Larvae of the fall armyworm were sampled by inspecting 120 randomly chosen plants (10 maize plants per experimental plot). Evaluations were made weekly from seedling emergence until flowering, the period in which plants were more susceptible to attack. One weeding and two fertilizer side dressings were conducted during the maize cycle.

\section{Statistical Analyses}

To evaluate the population dynamics of the fall armyworm repeated measures ANOVA were carried out in Statistica 8.0 (StatSoft Inc 19842007), followed by post hoc Fisher LSD tests. Linear regressions $(\mathrm{P}<0.05)$ were used to test the influence of forest distance on the species richness and abundance of predatory wasps as well as on the abundance of the fall armyworm. Pearson correlations were conducted between the species richness and abundance of predatory wasps and the abundance of the fall armyworm. Data were $\sqrt{n+1}$ transformed to achieve normality whenever necessary.

\section{RESULTS}

A total of 46 predatory solitary wasps, 26 Pachodynerus guadulpensis Saussure (Vespidae), 11 Isodontia sp. (Sphecidae) and 9 Trypoxylon nitidum Smith (Crabronidae) were collected. There were no significant differences in the fall armyworm abundance between the lines with and without trap nests $\left(\mathrm{F}_{1.118}=2.47 ; \mathrm{P}=0.118\right)$. The abundance of the fall armyworm varied throughout the time and peaked at 56 days after maize emergence (Fig. 2a: $F_{9.106}=8.68 ; \mathrm{P}<0.0001$ ). The interaction between the lines (with and without trap nests) and time was not significant (Fig. 2b: $\left.\mathrm{F}_{9.1062}=1.51 ; \mathrm{P}=0.138\right)$.

(b)

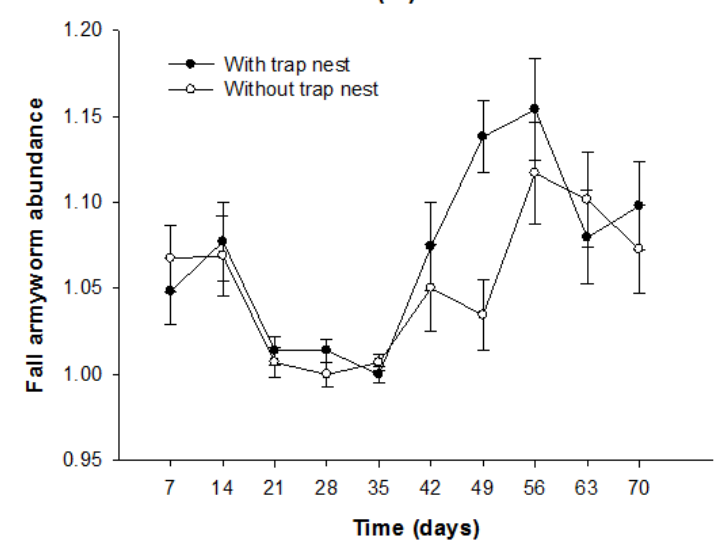

Figure 2 - Fall armyworm abundance per plant in relation to: a) time; b) interaction between lines with/without trap nests and time. Repeated Measures ANOVA followed by post hoc Fisher LSD tests. Mean values $\pm \mathrm{SE}$ are given. 
Predatory wasp abundance decreased (Fig. 3a; $y=$ $2.608-3.88 x ; \mathrm{R}^{2}=0.18 ; \mathrm{F}_{1.22}=5.054 ; \mathrm{P}=0.034$ ) while the fall armyworm abundance increased (Fig. $3 b ; y=1.712+54.602 x ; \mathrm{R}^{2}=0.10 ; \mathrm{F}_{1.58}=$ $6.278 ; \mathrm{P}=0.015$ ) with the distance from the forest. Population densities of predatory wasps and the fall armyworm were negatively correlated according to the Pearson correlation $\left(\mathrm{r}_{\mathrm{p}}=-0.89 ; \mathrm{P}=\right.$ 0.017). The species richness of predatory wasps was not affected by the forest distance (Fig. 3c; $y=$ $1.120+0.0006 x ; \mathrm{R}^{2}=0.003 ; \mathrm{F}_{1.22}=0.860 ; \mathrm{P}=$ 0.363 ) nor was it correlated to the abundance of the fall armyworm $\left(\mathrm{r}_{\mathrm{p}}=0.44 ; \mathrm{P}=0.375\right)$.
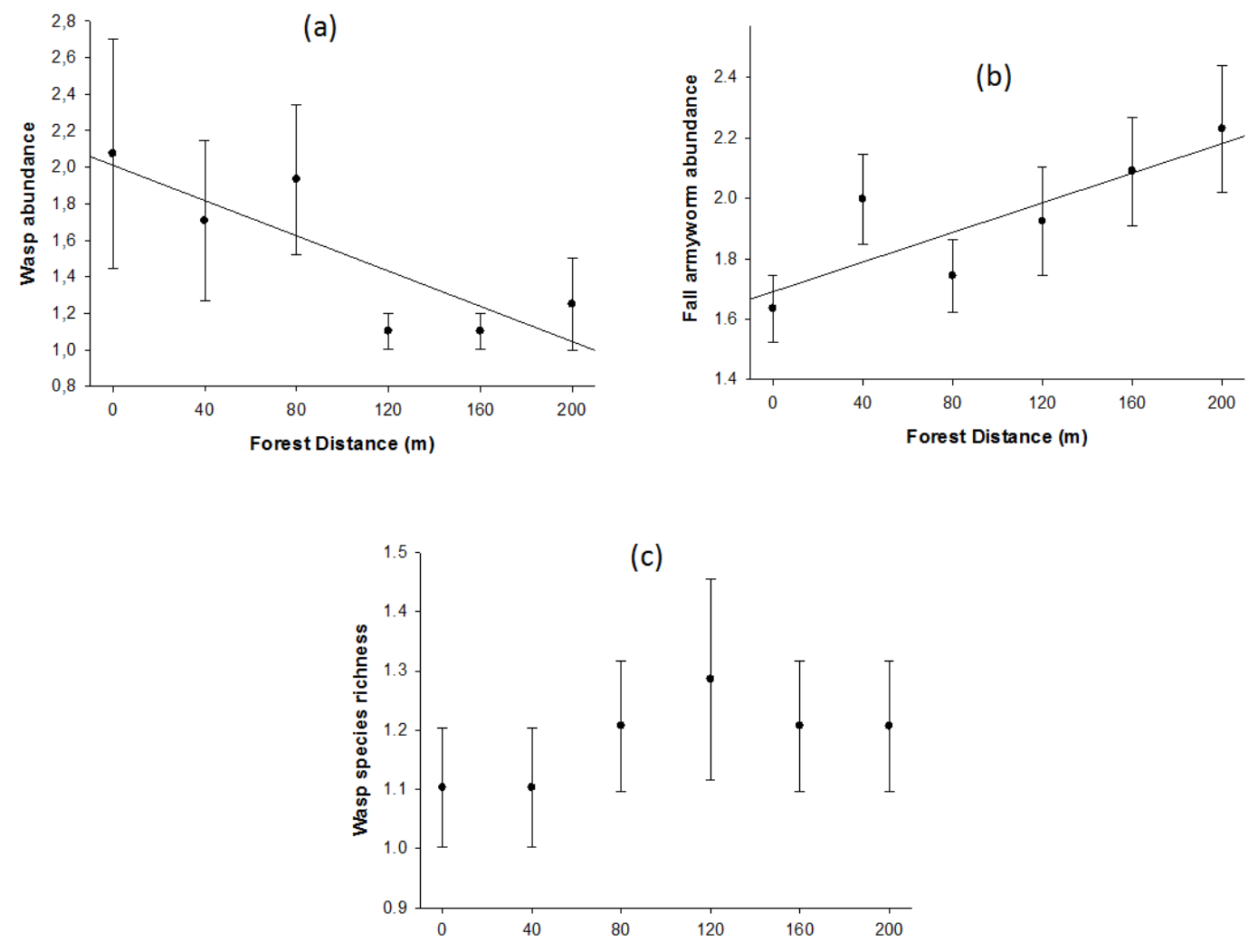

Figure 3 - Abundances of predatory solitary wasps per trap nest (a) and the fall armyworm per plant (b) and species richness of predatory solitary wasps per trap nest (c) in relation to the forest distance. Linear regression analyses with 5\% of likelihood. Mean values \pm SE are given.

\section{DISCUSSION}

Only three predatory solitary wasp species were found in the area. This low species richness might be due to the small size of the forest fragment, which could not support a higher species richness (Tscharntke et al., 2007). Additionally, the forest is a remnant of a secondary forest, and for some arthropods, secondary forests may harbour lower species richness than mature forests (Veddeler et al., 2005).

The abundance of both predatory solitary wasps and the fall armyworm was affected by the forest distance, but species richness of predatory solitary wasps did not respond to increasing forest distance. Overall, the proximity of the forest benefited predatory solitary wasps and reduced the abundance of the fall armyworm.

Trap nests can be used to increase the predatory solitary wasp population in order to improve the biological pest control in agroecosystems (Gathmann and Tscharntke, 1997). However, it was not so in the present study. This was probably due to the short distance between the lines with and without trap nests since this distance was probably smaller than the predatory solitary wasps' flying range (Klein et al., 2004). 
Predatory solitary wasp abundance was negatively correlated while the abundance of the fall armyworm was positively related to the distance of the forest showing that forest habitats increased the local abundance of cavity-nesting wasps. Forest remnants provide nesting sites and other resources scarce or absent in simplified landscapes, such as permanent vegetation cover, refuge from disturbance, alternative prey and nectar (Tscharntke et al., 2007; Sobek et al., 2009). Therefore, forest fragments may harbour natural enemy populations, which may spill over into agricultural fields, eventually enhancing the natural biological control (Tscharntke et al., 2005; Holzschuh et al., 2009). Increasing forest distance may reduce the predatory solitary wasp populations which can lead to lower predation and consequently increase the problems with the fall armyworm.

In contrast to previous findings showing high wasp diversity near the forest fragments (Klein et al., 2006; Holzschuh et al., 2009), no correlation was found between the species richness of predatory solitary wasps and forest distance. From all the species found, only $P$. guadulpensis was a caterpillar hunter (Buschini and Buss, 2010). Isodontia sp. provides its nests with nymphs of Orthoptera while T. nitidum feeds its larvae with spiders (Soares et al., 2001; Santoni and Del Lama, 2007). Pachodynerus guadulpensis was, therefore, probably the natural biological control agent of the fall armyworm in maize this study.

In conclusion, forest fragments in the vicinity of crops such as maize could enhance the biological control carried out by the predatory solitary wasps helping to regulate the populations of pests like the fall armyworm in maize.

\section{ACKNOWLEDGEMENTS}

We thank Bolívar R. Garcete Barret and Marcel G. Hermes (Universidade Federal do Paraná, Departamento de Zoologia) for their contribution in wasp species identification. We also thank Daniele L. Vieira for fieldwork assistance, the Maranhão State University (UEMA) and the Maranhão State Research Foundation (FAPEMA) for granting scholarships to the first second and second authors and two anonymous reviewers for helpful comments on the manuscript. AVT was supported by PNPD/CAPES, Brasília, Brazil.

\section{REFERENCES}

Buschini, M. L. T. and Buss, C. E. (2010), Biologic aspects of different species of Pachodynerus (Hymenoptera; Vespidae; Eumeninae). Braz. J. Biol., 70, 623-629.

Cesconetto, A. O.; Favero, S.; Oliveira, A. K. M. de and Souza, C. C. de (2005), Distribuição espacial do dano da lagarta-do-cartucho do milho Spodoptera frugiperda (J.E. Smith, 1797), em Sidrolândia, Mato Grosso do Sul. Ensaios e ci., 9, 305-314.

Clough, I.; Kruess, A.; Klein, D. and Tscharntke, T. (2005), Spider diversity in cereal fields: comparing factors at local, landscape and regional scales. $J$. Biogeogr., 32, 2007-2014.

Davies, K. F.; Marguels, C. R. and Lawrence, J. F. (2000), Which traits of species predict population declines in experimental forest fragments? Ecology, 81, 1450-1461.

Didham, R. K.; Ghazoul, J.; Stork, N. E. and Davis, A. J. (1996), Insects in fragmented forests: a functional approach. Trends Ecol. Evol., 11, 255-260.

Empresa Brasileira de Pesquisa Agropecuária (EMBRAPA) (2006), Sistema Brasileiro de Classificação de Solos. Embrapa Solos, Rio de Janeiro, pp. 306.

Gathmann, A. and Tscharntke, T. (1997), Bees and wasps in the agricultural landscape: colonization and augmentation in trap nests. Mitt. Dtsch. Ges. Allg. Angew. Entomol., 11, 91-94.

Harris, A. C. (1994), Ancistrocerus gazella (Hymenoptera: Vespoidea: Eumenidae): a potentially useful biological control agent for leafrollers Planotortrix octo, P. excessana, Ctenopseustis obliqua, C. herana, and Epiphyas postvittana (Lepidoptera: Tortricidae) in New Zealand. New Zeal. J. Crop Hort., 22, 235-238.

Holzschuh, A., Steffan-Dewenter, I. and Tscharntke, T. (2009), Grass strip corridors in agricultural landscapes enhance nest site colonisation by solitary wasps. Ecol. Appl., 19, 123-132.

Klein, A. M.; Steffan-Dewenter, I.; Buchori, D. and Tscharntke, T. (2002a), Effects of land-use intensity in tropical agroforestry systems on coffee flowervisiting and trap-nesting bees and wasps. Conserv. Biol., 16, 1003-1014.

Klein, A. M.; Steffan-Dewenter, I. and Tscharntke, T. (2002b), Predator-prey ratios on cocoa along a landuse gradient in Indonesia. Biodivers. Conserv., 11, 683-693.

Klein, A. M.; Steffan-Dewenter, I. and Tscharntke, T. (2004), Foraging trip duration and density of megachilid bees, eumenid wasps and pompilid wasps in tropical agroforestry systems. J. Anim. Ecol., 73, 517-525. 
Klein, A. M.; Steffan-Dewenter, I. and Tscharntke, T. (2006), Rain forest promotes trophic interactions and diversity of trap-nesting Hymenoptera in adjacent agroforestry. J. Anim. Ecol., 75, 315-323.

LABGEO (2002), Atlas do Maranhão. UEMA, São Luis, pp. 39.

Laurance, V. F. and Bierregaard Jr., R. O. (1997), Tropical Forest Remnants. The University of Chicago Press, Chicago.

Losey, J. E. and Vaughan, M. (2006), The economic value of ecological services provided by insects. Bioscience, 56, 311-323.

Millennium Ecosystem Assessment (MEA) (2005), Ecosystems and human well-being: synthesis. Island Press, Washington.

Santoni, M. M. and Del Lama, M. A. (2007), Nesting biology of the trap-nesting Neotropical wasp Trypoxylon (Trypargilum) aurifrons Shuckard (Hymenoptera, Crabronidae). Rev. Bras. entomol., 51, 369-376.

Schelhas, J. and Greenberg, R. (1996), Forest Patches in Tropical Landscapes. Island Press, Washington.

Soares, L. A.; Zanette, L. R. S.; Pimenta, H. R., Gonçalves, A. M. and Martins, R. P. (2001), Nesting biology of Isodontia costipennis (Spinola) (Hymenoptera: Sphecidae). J. Hymenopt. Res., 10, 245-250.

Sobek, S.; Tscharntke T.; Scherber C.; Schiele, S. and Steffan-Dewenter, I. (2009), Canopy vs. understory: does tree diversity affect bee and wasp communities and their natural enemies across forest strata? Forest Ecol. Manag., 258, 609-615.
Tscharntke, T.; Gathmann, A. and Steffan-Dewenter, I. (1998), Bioindication using trap-nesting bees and wasps and their natural enemies: community structure and interactions. J. Appl. Ecol., 35, 708-719.

Tscharntke, T.; Rand, T. A. and Bianchi, F. J. J. A. (2005), The landscape context of trophic interactions: insect spillover across the crop-noncrop interface. Ann. Zool. Fenn., 42, 421-432.

Tscharntke, T.; Bommarco, R.; Clough, Y.; Crist, T. O.; Kleijn, D.; Rand, T. A.; Tylianakis, J. M.; van Nouhuys, S. and Vidal, S. (2007), Conservation biological control and enemy diversity on a landscape scale. Biol. Control, 43, 294-309.

Tylianakis, J. M.; Klein, A. M. and Tscharntke, T. (2005), Spatiotemporal variation in the diversity of hymenoptera across a tropical habitat gradient. Ecology, 12, 3296-3302.

Veddeler, D.; Schulze, C. H.; Steffan-Dewenter, I.; Buchori, D. and Tscharntke, T. (2005), The contribution of tropical secondary forest fragments to the conservation of fruit-feeding butterflies: effects of isolation and age. Biodivers. Conserv., 14, 35773592.

Western, D. and Pearl, M. C. (1989), Conservation for the twenty-first century. Oxford University Press, New York.

Wyckhuys, K. A. G. and O’Neil, R. J. (2006), Population dynamics of Spodoptera frugiperda Smith (Lepidoptera: Noctuidae) and associated arthropod natural enemies in Honduran subsistence maize. Crop Prot., 25, 1180-1190. 